NOTAS

\title{
Ficus enormis cuttings rooting: concentrations of indole butyric acid and seasonal variations
}

\author{
Enraizamiento de esquejes de Ficus enormis: \\ concentraciones de ácido indol butírico y variaciones estacionales
}

\author{
Rosimeri de Oliveira Fragoso ${ }^{\text {a* }}$, Carlos André Stuepp a , Antonio Aparecido Carpanezzi ${ }^{\text {b }}$ \\ Ivar Wendling b, Katia Christina Zuffellato-Ribas c, Henrique Soares Koehler c

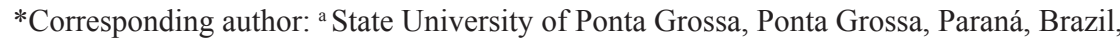 \\ tel.: 55-42-32203126, meri_ol@yahoo.com.br \\ ${ }^{\mathrm{b}}$ Embrapa Forest, Colombo, Paraná, Brazil. \\ c Federal University of Paraná, Curitiba, Paraná, Brazil.
}

\begin{abstract}
SUMMARY
Plants producing fruits for many months of the year, or at times when few species bear fruits, are highly valuable for restoration of degraded ecosystems due to their ability to attract and support dispersing fauna. An example of this are native fig trees such as Ficus enormis. Thus, in view of the difficulties for $F$. enormis seedlings production, we aimed at developing a method of cuttings propagation by evaluating the rooting and root vigor of cuttings from a field clonal garden. The experiment was established between June/2015 and May/2016 at Laboratory of Forest Species Propagation of Embrapa Florestas, in Colombo-PR. We evaluated collection of cuttings during three seasons (winter, spring and summer) and application of concentrations of indole-3-butyric acid - IBA (0, 1000, 2000, $\left.3000,4000,5000 \mathrm{mg} \mathrm{L}^{-1}\right)$. After 45 days of cuttings establishment in an acclimatized greenhouse, the best results for rooting, number of roots, average length of the three largest roots per cutting and maintenance of leaves and shoots were found in spring and summer. Using plant regulator did not influence the rooting or root vigor of propagules; the time of the year was the predominant factor to induce rooting. The results show that the cuttings technique with propagules from a clonal garden is efficient for producing $F$. enormis plants and can serve as a basis for the species propagation.
\end{abstract}

Key words: epicormic shoots, native species of Brazil, plant propagation, root vigor, vegetative propagation.

\section{RESUMEN}

Las plantas que producen frutos durante muchos meses del año, o en momentos en que pocas especies dan frutos, son de gran valor para la restauración de ecosistemas degradados debido a su capacidad para atraer y apoyar la fauna dispersora. Un ejemplo de esto son las higueras nativas como Ficus enormis. Por las dificultades para la producción de plántulas de F. enormis, fue evaluada la propagación de esquejes mediante enraizamiento y vigor de sus raíces de un jardín clonal de campo. El experimento se estableció entre junio/2015 y mayo/2016 en el Laboratorio de Propagación de Especies Forestales de Embrapa Florestas, en Colombo-PR. Se evaluó la recolección de esquejes durante tres estaciones (invierno, primavera y verano) y la aplicación de concentraciones de ácido indol-3-butírico - IBA (0, 1000, 2000, 3000, 4000, $\left.5000 \mathrm{mg} \mathrm{L}^{-1}\right)$. Después de 45 días de establecimiento de esquejes en un invernadero climatizado, los mejores resultados para el enraizamiento, el número de raíces, la longitud promedio de las tres raíces más grandes por corte, el mantenimiento de las hojas y los brotes se encontraron en primavera y verano. El uso del regulador de la planta no influyó en el enraizamiento y el vigor de las raíces de los propágulos, y la época del año fue el factor predominante para inducir el enraizamiento. Los resultados muestran que la técnica de esquejes con propágulos de un jardín clonal es eficiente para producir plantas de $F$. enormis y puede servir como base para la propagación de esta especie.

Palabras clave: brotes epicórmicos, especies nativas de Brasil, propagación de plantas, vigor de raíz, propagación vegetativa.

\section{INTRODUCTION}

In Brazil, degraded ecosystems have often been restored by planting mixed plots of tree species and by phy- sically protecting the area (Rodrigues et al. 2009). When well designed and executed, mixed plots can help restore such areas. In this case, species are chosen to favor natural succession (Carpanezzi and Nicodemo 2009). In ge- 
neral, plants that produce fruits for many months of the year, or in times when few species bear fruits, are highly valuable. Thus, an important step to increase the chances of successful restoration of degraded areas is choosing the species to be used (Volis 2016). However, many important species are not available in nurseries, which is frequently an obstacle. Such absence is due to the lack of information about the collection, processing, storage and germination of seeds, caused by the high heterogeneity and complexity of ecophysiological strategies that native species present (Pilon and Durigan 2013).

One example of this are the native fig trees of the $\mathrm{Fi}$ cus genus, such as Ficus enormis Mart. ex Miq., which are considered important components in ecosystem dynamics as they attract dispersing fauna (Carpanezzi and Nicodemo 2009). Ficus enormis (family Moraceae) is an early secondary, evergreen species (Marmontel et al. 2013) that naturally occurs in the Northeast, Midwest, Southeast and Southern regions of Brazil, and is found in Caatinga, Cerrado and Atlantic Forest Biomes (REFLORA 2019). Adult trees are large, commonly reaching $25 \mathrm{~m}$ in height and up to $1.80 \mathrm{~m}$ in diameter at breast height (Pelissari and Romaniuc Neto 2013). Despite its importance in restoration, this species is frequently not found in nurseries due to its small sized seeds and the difficulty in processing and handling them.

Due to the difficulties in F. enormis seedlings production, rooted cuttings appear as a viable and relatively fast alternative of asexual reproduction, becoming more efficient as propagation protocols are established. Including vegetatively propagated seedlings is justified by the importance of including functional groups in restoration works, and the genetic basis of the species can be supplied by collecting cuttings from many matrices (Carpanezzi and Carpanezzi 2006). The factors responsible for successful rooting cuttings, as substrates, rooting environment, type of propagule and use of plant regulators, vary for each species (Santos et al. 2011), and it is essential to obtain viable propagules with good rooting capacity.

The maturation of propagules (ontogenetic ageing) is a determining factor in the adventitious rhizogenesis process. Propagules with a higher degree of juvenility tend to have superior rooting and root vigor (Stuepp et al. 2018). One technique used to maintain the juvenility of propagules is continuous pruning of the stock plants aiming at the induction of epicormic shoots (Heide 2018). However, few studies have evaluated the effect of this in native tree species of Brazil. Environmental influences, promoted by the different seasons, can also act on the endogenous levels of auxin of mother plants, influencing the cuttings rooting (Tombesi et al. 2015). For some species that have low endogenous concentrations of plant hormones linked to rhizogenesis, the application of synthetic auxins may contribute to increase the amount of free auxins in the propagules, favoring the process of root induction, and thus, the success of vegetative propagation (Pacurar et al. 2014). The addition of auxin has been verified in many species and the necessary concentrations vary from species to species (Santos et al. 2011).

Thus, aiming at developing an efficient protocol for $F$. enormis rooted cuttings production, the objective of this stu$\mathrm{dy}$ is to evaluate the effect of different concentrations of the synthetic auxin indole-3-butyric acid (IBA) on rooting and root vigor of stem cuttings from epicormic shoots derived from a clonal field garden, during three different seasons.

\section{METHODS}

The experiment was established between June/2015 and May/2016 at Laboratory of Forest Species Propagation of Embrapa Florestas, in Colombo-PR (25 20' S and 49 $14^{\prime}$ $\mathrm{W}, 950 \mathrm{~m}$ ). The local climate is Cfb type (Köppen classification), with average annual temperature of $16.6^{\circ} \mathrm{C}$ and average annual rainfall of $1596 \mathrm{~mm}$, without water deficit and with frosts occurring in autumn and winter (figure 1).

The cuttings were obtained from stock plants stablished in 2001 in a field clonal garden, with $2 \mathrm{~m} \times 1 \mathrm{~m}$ spacing, in the city of Colombo-PR, Brazil. To reinvigorate the stock plants, they were drastically pruned in March/2015, lowering them to an average height of $0.3 \mathrm{~m}$ from the soil to induce the emission of epicormic shoots. From this, shoots were collected for cuttings preparation and rooting in winter/2015, spring/2015 and summer/2016. Stem cuttings with $8 \pm 1 \mathrm{~cm}$ in length and diameter ranging from $0.4 \pm$ $0.2 \mathrm{~mm}$ were made, maintaining two leaves in the terminal portion, reduced to $1 / 3$ of their original surface area.

Cuttings received phytosanitary treatment with sodium $0.5 \%$ hypochlorite solution for 10 minutes (bactericidal action) and were washed in running water for 10 minutes. Subsequently, the cuttings base was treated with indole3-butyric acid (IBA) at concentrations of 0, 1000, 2000, 3000,4000 and $5000 \mathrm{mg} \mathrm{L}^{-1}$, diluted in hydroalcoholic $(1: 1 \mathrm{v} / \mathrm{v})$ solution for 10 seconds. Rooting was carried out in $110 \mathrm{~cm}^{3}$ tubes, filled with medium-sized vermiculite and partially carbonized rice husk $(1: 1, \mathrm{v} / \mathrm{v})$. Afterwards, the cuttings were stablished in a greenhouse, with intermittent misting and controlled temperature $\left(20{ }^{\circ} \mathrm{C}\right.$ to $\left.30^{\circ} \mathrm{C}\right)$ and relative humidity over $90 \%$.

After forty-five days, we evaluated: percentage of rooted cuttings, number of roots/cutting, length of the three largest roots/cutting $(\mathrm{cm})$, percentage of cuttings with calluses, percentage of cuttings with roots and calluses, percentage of living cuttings that did not present root induction or callus formation, percentage of dead cuttings with necrotic tissues, percentage of cuttings with original leaves (living cuttings that maintained original leaf) and percentage of cuttings with shoots.

The experiment was set in a completely randomized design, with a factorial arrangement of 3 x 6 (3 seasons $x$ 6 IBA concentrations), with four replications. Each replication consisted of 20 cuttings. The homogeneity of variances was verified using the Bartlett test and, when the ANOVA test showed statistical significance $(P<0.05)$, the Tukey 


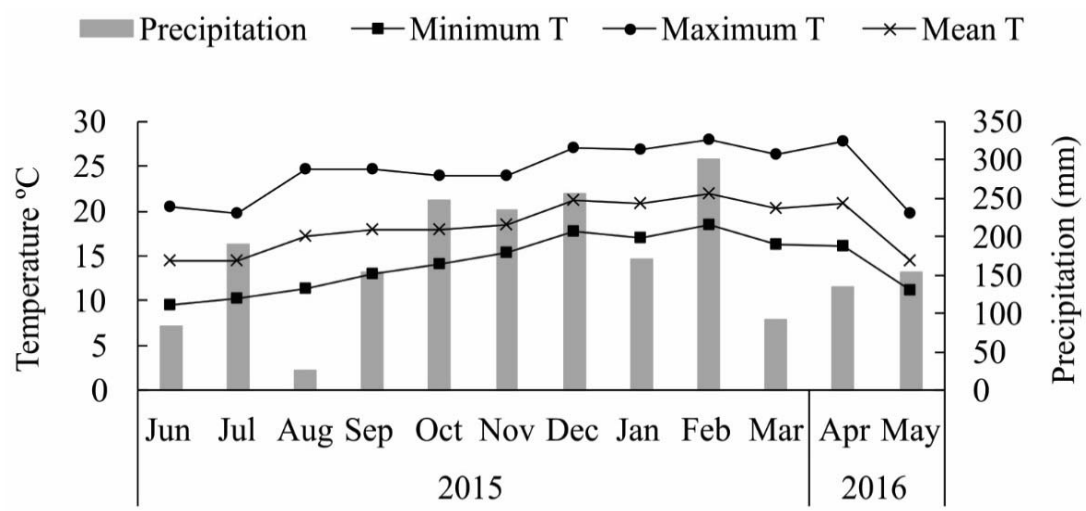

Figure 1. Maximum, minimum and average temperatures and accumulated rainfall in Colombo-PR, Brazil region between March/2015 and May/2016 (SIMEPAR/PR).

Temperaturas máximas, mínimas y medias y precipitaciones acumuladas en la región de Colombo-PR, Brasil, entre marzo/2015 y mayo/2016 (SIMEPAR/PR).

test was used to determine significant differences $(P<0.05)$ between individual means. To verify the relationship between percentage of rooted cuttings and the variables leaf maintenance and shoot emission, as well as with average temperatures of the region (figure 1), a Pearson's correlation analysis $(P<0.01$ and $P<0.05)$ was performed.

\section{RESULTS}

The ANOVA revealed a significant interaction between season and plant regulator factors for number of roots per cutting and percentage of cuttings with shoots. However, regarding factors individual analyses, seasons significantly affected all variables analyzed. For IBA application, there was a significant difference for number of roots per cutting and percentages of cuttings with calluses and with shoots.

In general, the variables that responded to the interaction between season and plant regulator presented higher values in spring and summer, under the concentrations of $4000 \mathrm{mg} \mathrm{L}^{-1}$ and $5000 \mathrm{mg} \mathrm{L}^{-1}$ (table 1).

These results are confirmed by the individual analysis of the factors. These revealed higher rooting percentages, number of roots and average length of the three largest roots per cutting and percentages of leaf maintenance and shoot emission in the warmer seasons (figure 2). On the other hand, we observed the highest percentages of cuttings with calluses, living cuttings without roots or calluses and dead cuttings in winter, however with values below $20 \%$.

The correlation analysis between average temperatures of each season and rooting percentages showed a positive correlation of 0.95 . Cuttings rooting presented positive correlations of 0.70 and 0.60 in relation to leaf maintenance and shoot emission, respectively.

Another important result refers to high callus formation in rooted cuttings, especially in spring and summer (figure 3). In these seasons, more than $80 \%$ of the rooted cuttings presented callus formation.

\section{DISCUSSION}

Studies indicate that during the hottest periods of the year, many plants experience intense vegetative growth, thus, produce higher amounts of auxins, carbohydrates and rooting cofactors (Salmi and Hesami 2016). High temperatures, along with higher precipitation and radiation, directly interfere in growth and development of apical meristems, which are the main sites for auxin synthesis in plants (Zhao 2018). However, during the winter, when temperatures are lower, woody plants become dormant to protect their meristems by reducing exchange rate activities and increasing concentrations of phenolic compounds and inhibitors, which temporarily ceases their growth (Ding and Nilsson 2016). Thus, the highest concentrations of endogenous auxins, possibly present in the parent plants during spring and summer, and lowest concentration of inhibitors may have been responsible for the production of more vigorous shoots, favoring the highest rooting percentages. In fact, the correlation analysis between average temperatures of each season and rooting percentages showed a positive correlation close to 1.00 , which has also been verified in other studies (Fragoso et al. 2015). Similarly, the higher number of roots values and average length of the three largest roots per cutting demonstrate the high root vigor of the cuttings collected in these seasons, which may reflect on the stability, survival and development of seedlings in the field (Stuepp et al. 2017).

Nevertheless, even the lowest rooting percentages obtained in winter were higher than $60 \%$, regardless of the IBA application, which is possibly related to the vigor of the used cuttings (Nascimento et al. 2018). As already mentioned, materials with a higher degree of juvenili- 
Table 1. Averages of number of roots per cutting and percentage of cuttings with shoots in $F$. enormis cuttings, installed in three seasons under six concentrations of indole-3-butyric acid (IBA).

Promedios de número de raíces por esqueje y porcentaje de esquejes con brotes en esquejes de $F$. enormis, instalados en tres estaciones bajo seis concentraciones de ácido indol-3-butírico (IBA).

\begin{tabular}{|c|c|c|c|c|c|c|c|}
\hline \multicolumn{8}{|c|}{ Number of roots per cutting } \\
\hline $\operatorname{IBA}\left(\mathrm{mg} \mathrm{L}^{-1}\right)$ & \multicolumn{2}{|c|}{ Winter } & \multicolumn{2}{|c|}{ Spring } & \multicolumn{3}{|l|}{ Summer } \\
\hline 0 & $6.28 \mathrm{a}$ & A & $10.91 \mathrm{c}$ & A & 10.43 a & & A \\
\hline 1000 & $7.89 \mathrm{a}$ & $\mathrm{B}$ & $12.16 \mathrm{bc}$ & $\mathrm{AB}$ & $13.54 \mathrm{a}$ & a & A \\
\hline 2000 & $9.04 \mathrm{a}$ & A & $12.38 \mathrm{bc}$ & A & $12.14 \mathrm{a}$ & a & A \\
\hline 3000 & $12.49 \mathrm{a}$ & A & $13.50 \mathrm{bc}$ & A & $11.80 \mathrm{a}$ & a & A \\
\hline 4000 & $11.70 \mathrm{a}$ & B & $18.22 \mathrm{ab}$ & A & $11.55 \mathrm{a}$ & a & B \\
\hline 5000 & $11.30 \mathrm{a}$ & B & 23.53 a & A & $10.00 \mathrm{a}$ & $\mathrm{a}$ & B \\
\hline \multicolumn{8}{|c|}{ Coefficient of variation $=24.83 \%$} \\
\hline \multicolumn{8}{|c|}{ Percentage of cuttings with shoots (\%) } \\
\hline $\operatorname{IBA}\left(\mathrm{mg} \mathrm{L}^{-1}\right)$ & \multicolumn{2}{|c|}{ Winter } & \multicolumn{2}{|c|}{ Spring } & \multicolumn{3}{|l|}{ Summer } \\
\hline 0 & $62.50 \mathrm{a}$ & $\mathrm{AB}$ & $45.00 \mathrm{bc}$ & B & 87.50 a & a & A \\
\hline 1000 & $60.71 \mathrm{a}$ & $\mathrm{AB}$ & $41.25 \mathrm{c}$ & B & $77.50 \mathrm{a}$ & a & A \\
\hline 2000 & $69.64 \mathrm{a}$ & A & $66.25 \mathrm{abc}$ & A & $81.25 \mathrm{a}$ & a & A \\
\hline 3000 & $66.07 \mathrm{a}$ & B & $92.50 \mathrm{a}$ & A & $77.50 \mathrm{a}$ & a & A \\
\hline 4000 & 58.93 a & B & $83.75 \mathrm{a}$ & $\mathrm{AB}$ & $91.25 \mathrm{a}$ & a & A \\
\hline 5000 & $76.79 \mathrm{a}$ & A & $72.50 \mathrm{ab}$ & A & $87.50 \mathrm{a}$ & $\mathrm{a}$ & A \\
\hline
\end{tabular}

Coefficient of variation $=20.51 \%$

Averages followed by the same lower case letter in column and capital letter on the line do not differ among them at $P<0.05$ using Tukey test.

ty tend to have higher concentrations of free auxins and, consequently, superior rooting and root vigor (Stuepp et al. 2018). In F. enormis, the high rooting percentages, regardless of the IBA application, suggest that the presence of auxins was not a limiting factor. The high concentration of free auxins in propagules with a higher degree of juvenility may be related to the reduced activity of peroxidase enzymes in these materials, which would be responsible for the degradation of endogenous auxins (Wendling et al. 2014). Studies also suggest that different auxin transport mechanisms may be involved in the larger availability of this hormone in juvenile propagules, favoring the high rooting percentages of these materials compared to propagules with a higher degree of maturity (Nakhooda et al. 2011, Stuepp et al. 2017). In the present study, the high vigor of the material used also demonstrates the efficiency of continuous pruning of $F$. enormis stock plants established in a field clonal garden to provide propagules with a higher degree of juvenility and good aptitude for adventitious rooting. Nonetheless, in the Mixed Ombrophilous Forest, frosts can affect $F$. enormis shoots in a clonal garden. Therefore, it is often not possible to obtain cuttings in the coldest autumnwinter period, usually from May 15 to the end of August.
Similarly, the variables leaf maintenance and shoot emission were high (above $60 \%$ ) during all three seasons, although, significantly higher values were obtained in spring and summer when compared to winter (figure 2). As observed in other species (Fragoso et al. 2015, Tombesi et al. 2015), these results show a positive relationship between the variables leaf maintenance and cutting rooting, which presented a $70 \%$ correlation. This relationship is, possibly, due to the supply of carbohydrates and hormones present in leaves, demonstrating the importance of maintaining them as essential metabolites for the rooting process (Tombesi et al. 2015). Similarly, regarding the emission of shoots, the positive correlation with rooting suggests that the process of shoot formation was not harmful to root system induction in $F$. enormis during any of the evaluated seasons. In some species, the emission of shoots prior to rooting can lead to the depletion of carbohydrates and auxins present in the propagules that would be required in the rhizogenesis process, making it difficult to form adventitious roots (Hartmann et al. 2011). In F. enormis, however, the rooting of the cuttings started very early, about 2-3 weeks after installation, favoring the formation of roots prior to the shoots emission. 
A

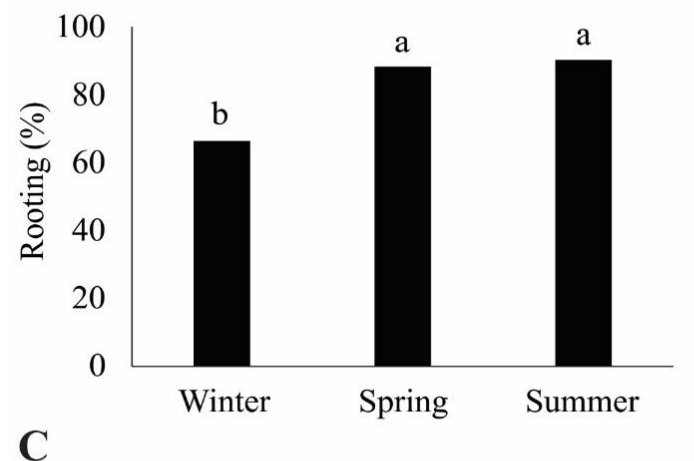

C

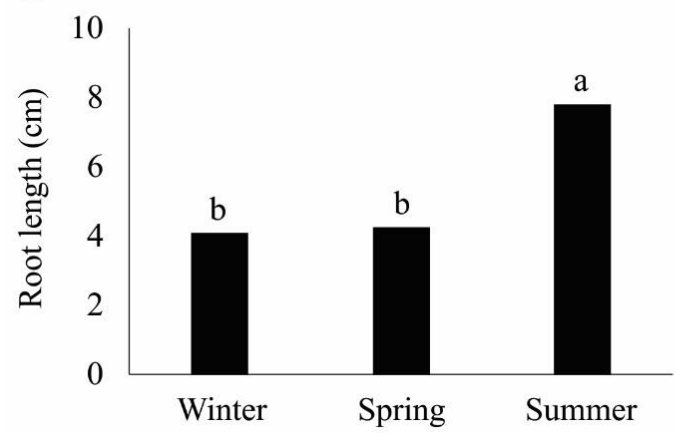

E

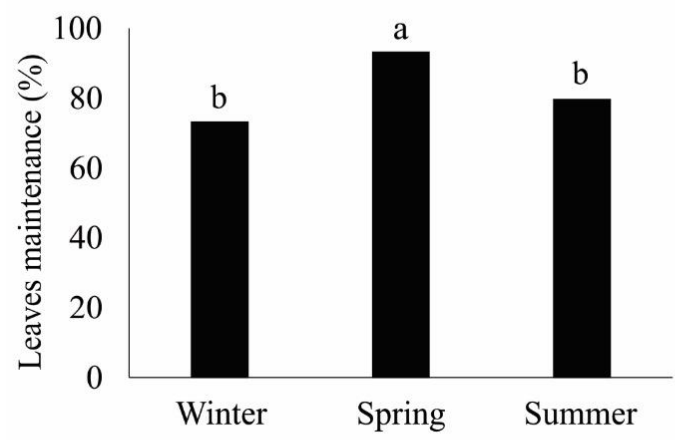

G

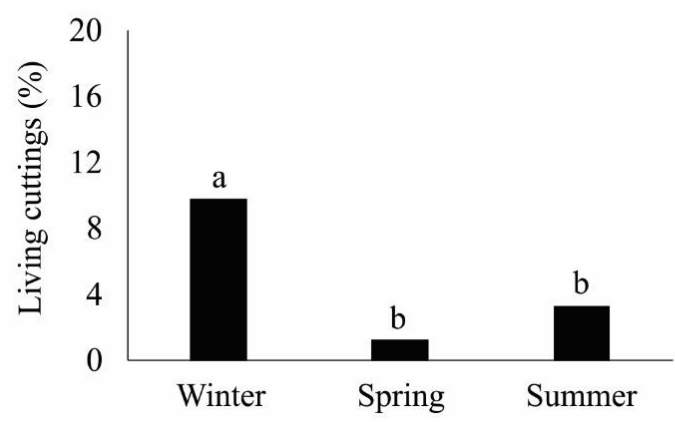

B

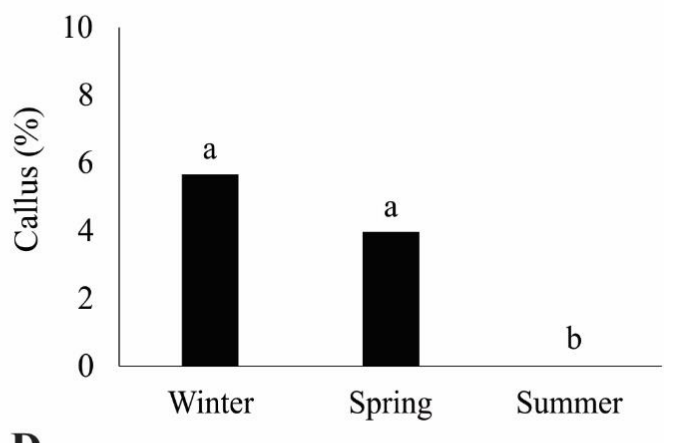

D

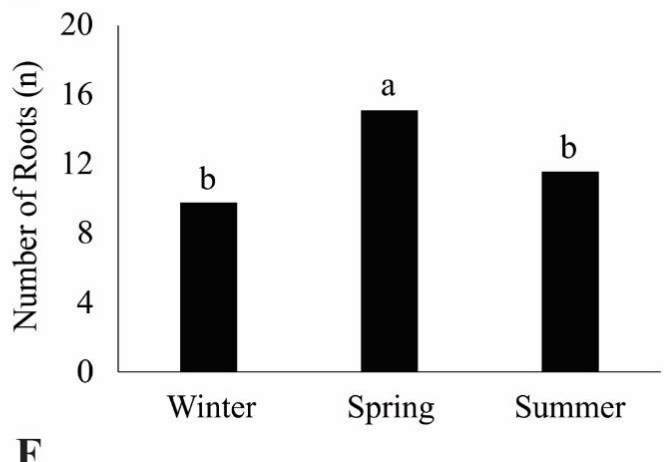

F

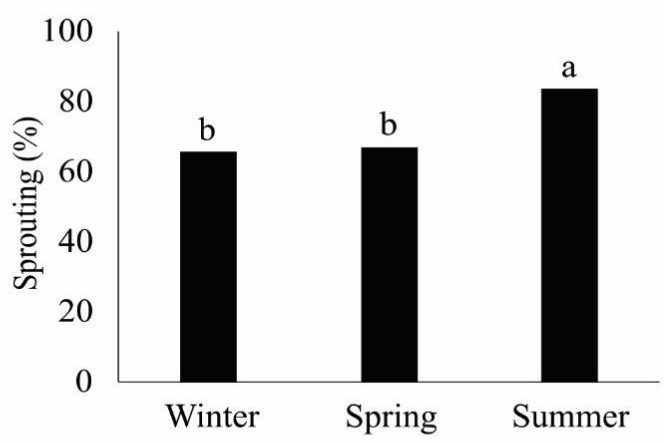

H

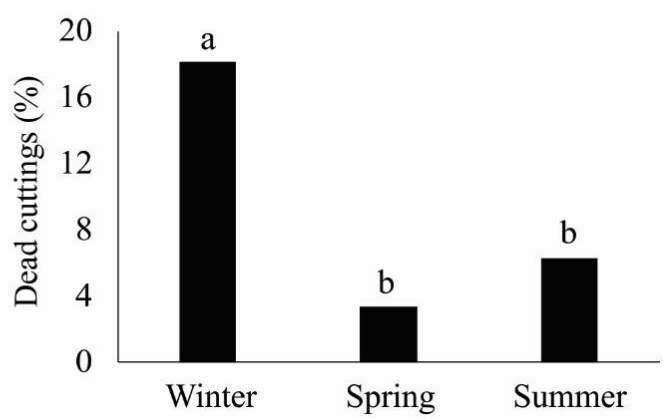

Figure 2. Averages of rooting (A), callus formation (B), average length of the three largest roots per cutting (C), number of roots per cutting (D), leaf maintenance (E), shoot emission (F), living cuttings without roots or calluses $(\mathrm{G})$ and dead cuttings $(\mathrm{H})$ in $F$. enormis cuttings installed in three seasons.

Promedios de enraizamento (A), formación de calos (B), longitud promedio de las tres raíces más grandes por esqueje (C), número de raíces por esqueje (D), mantenimiento de hojas (E), emisión de brotes (F), esquejes vivos sin raíces o callosidades (G) y esquejes muertos (H) en esquejes de F. enormis instalados en tres estaciones. 


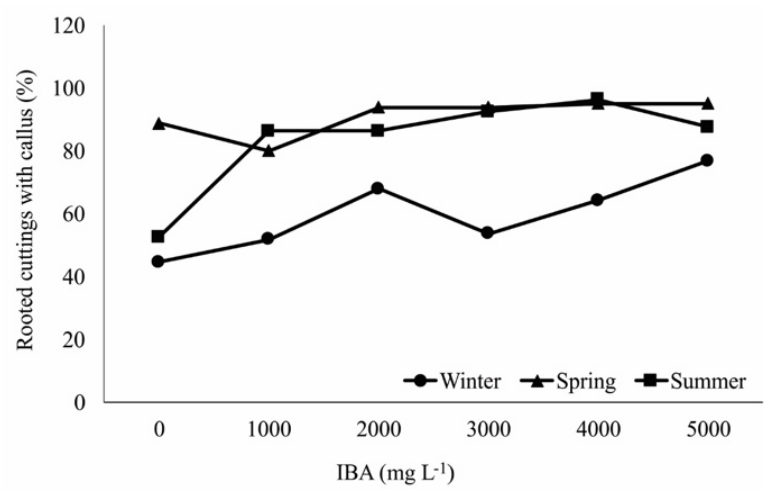

Figure 3. Percentage of cuttings with roots and calluses for $F$. enormis, installed in three seasons and under six concentrations of indole-3-butyric acid (IBA).

Porcentaje de esquejes con raíces y callosidades para $F$. enormis, instalados en tres estaciones y bajo seis concentraciones de ácido indol-3-butírico (IBA).

The analysis of callus formation revealed values below $6 \%$ in all seasons. However, the high presence of calluses in rooted cuttings, especially in spring and summer $(>80 \%)$, indicates possible indirect root formation (Rasmussen and Hunt 2010). The presence of calluses is undesirable for plant propagation, as their presence in the vascular connection region may limit the appropriate rhizogenesis process, compromising root functionality (Monder et al. 2017). However, this relationship varies depending on the species. The indirect formation of the root system is common during the regeneration of many plant species and has been considered a consequence of the maturation of vegetative propagules (Wendling et al. 2014). For F. enormis, however, more in-depth studies are needed to understand these changes and their consequences on the vegetative propagation of the species.

The lowest percentages of living cuttings without roots or calluses and dead cuttings in spring and summer are related to the highest percentages of cuttings rooted in these seasons. These results show the efficiency of the cuttings technique for vegetative propagation of $F$. enormis from epicormic shoots and the importance of using suitable propagules for rooting, particularly regarding the vigor and juvenility of the stock plants. It is important to highlight that there was no nutritional intervention in the stock plants in the field. The adequate supply of macro and micronutrients can favor the increase of the vegetative vigor of the stock plants and provide propagules with better morphophysiological and anatomical qualities (Zerche and Druege 2009). Non-nutritional replacement under long periods of management, however, can lead to the exhaustion of the stock plants, making their ability to supply propagules unfeasible.

The results found here consolidate the best options regarding the time of the year and support that IBA is not ne- cessary for rooting of $F$. enormis cuttings maintained in a field clonal garden. Along with results about other aspects, such as substrates, phases and environments (Fragoso et al. 2016), a guide for the daily production of $F$. enormis cuttings could be established in commercial nurseries.

\section{CONCLUSIONS}

Under the conditions in which the present work was carried out, it is possible to conclude that the vegetative propagation of $F$. enormis from epicormic shoots from clonal field garden is a viable method for this species seedlings production, without any plant regulator needed.

The use of plant regulator has no influence on rooting and root vigor of cuttings, being the time of the year the preponderant factor for root induction in cuttings of $F$. enormis.

\section{REFERENCES}

Carpanezzi AA, OTB Carpanezzi. 2006. Espécies nativas recomendadas para recuperação ambiental no Estado do Paraná, em solos não degradados. Colombo, Brasil. Embrapa Florestas. $52 \mathrm{p}$.

Carpanezzi AA, MLF Nicodemo. 2009. Recuperação de mata ciliar e reserva legal florestal no noroeste paulista. São Carlos, Brasil. Embrapa Pecuária Sudeste. 35 p.

Ding J, O Nilsson. 2016. Molecular regulation of phenology in trees - because the seasons they are a-changin'. Current Opinion in Plant Biology 29:73-79. DOI: https://doi. org/10.1016/j.pbi.2015.11.007.

Fragoso RO, CA Stuepp, KC Zuffellato-Ribas, G Macanhão, HS Koehler. 2015. Propagação vegetativa de Juniperus chinensis. Comunicata Scientae 6(3):307-316. DOI: https://doi. org/10.14295/CS.v6i3.825.

Fragoso RO, CA Stuepp, AA Carpanezzi, I Wendling, KC Zuffellato-Ribas, HS Koehler. 2016. Substratos renováveis na produção de mudas de Ficus enormis proveniente de jardim clonal. Pesquisa Florestal Brasileira 36(88):537-541. DOI: https://doi.org/10.4336/2016.pfb.36.88.1246.

Hartmann HT, DE Kester, FT Davies JR, RL Geneve. 2011. Hartmann \& Kerster's plant propagation: principles and practices. New Jersey, United States. Prentice Hall. 915 p.

Heide OM. 2019. Juvenility, maturation and rejuvenation in plants: adventitious bud formation as a novel rejuvenation process. The Journal of Horticultural Science and Biotechnology 94(1):2-11. DOI: https://doi.org/10.1080/14620316 .2018 .1482795 .

Marmontel CVF, VA Rodrigues, TM Martins, R Starzynski, JL Carvalho. 2013. Caracterização da vegetação secundária do bioma Mata Atlântica com base em sua posição na paisagem. Bioscience Journal 29(6):2042-2052. http://www. seer.ufu.br/index.php/biosciencejournal/article/view/18116

Monder MJ, P Kozakiewicz, A Jankowska. 2017. Effect of anatomical structure of shoots in different flowering phase on rhizogenesis of once-blooming roses. Notulae Botanicae Horti Agrobotanici Cluj-Napoca 45(2):408-416. DOI: https://doi.org/10.15835/nbha45210854.

Nakhooda M, MP Watt, D Mycock. 2011. Auxin stability and 
accumulation during in vitro shoot morphogenesis influences subsequent root induction and development in Eucalyptus grandis. Plant Growth Regulation 65:263-271. DOI: https://doi.org/10.1007/s10725-011-9597-7.

Nascimento B, ACS Sá, LBD Lemos, DPD Rosa, MDO Pereira, MC Navroski. 2018. Three epicormic shoot techniques in $I$. paraguariensis mother trees and its cutting according to the material rejuvenation degree. Cerne 24(3):240-248. DOI: https://doi.org/10.1590/01047760201824032584.

Pacurar DI, I Perrone, C Bellini. 2014. Auxin is a central player in the hormone cross-talks that control adventitious rooting. Physiologia Plantarum 151(1):83-96. DOI: https://doi. org/10.1111/ppl.12171.

Pelissari G, S Romaniuc Neto. 2013. Ficus (Moraceae) da Serra da Mantiqueira, Brasil. Rodriguésia 64(1):91-111. DOI: https://doi.org/10.1590/S2175-78602013000100009.

Pilon NAL, G Durigan. 2013. Critérios para indicação de espécies prioritárias para a restauração da vegetação de cerrado. Scientia Forestalis 41(99):389-399. https://www.ipef. br/publicacoes/scientia/nr99/cap10.pdf

Rasmussen A, MA Hunt. 2010. Ageing delays the cellular stages of adventitious root formation in pine. Australian Forestry 73(1):41-46. DOI: https://doi.org/10.1080/00049158.2010. 10676308 .

REFLORA. 2019. Ficus enormis Mart. ex Miq. In Plantas do Brasil: Resgate Histórico e Herbário Virtual para o Conhecimento e Conservação da Flora Brasileira. Jardim Botânico do Rio de Janeiro. Accessed 27 Nov. 2019. Available in http://floradobrasil.jbrj.gov.br/reflora/floradobrasil/ FB10160.

Rodrigues RR, RAF Lima, S Gandolfi, AG Nave. 2009. On the restoration of high diversity forests: 30 year experience in the Brazilian Atlantic Forest. Biological Conservation 142:1242-1251. DOI: https://doi.org/10.1016/j.biocon.2008.12.008.

Salmi MS, M Hesami. 2016. Time of collection, cutting ages, auxin types and concentrations influence rooting Ficus re- ligiosa L. stem cuttings. Journal of Applied Environmental and Biological Sciences 6(1):124-132.

Santos JP, AC Davide, LAF Teixeira, AJS Melo, LA Melo. 2011. Enraizamento de estacas lenhosas de espécies florestais. Cerne 17(3):293-301. DOI: https://doi.org/10.1590/S010477602011000300002.

Stuepp CA, I Wendling, SJ Trueman, H Koehler, KC Zuffellato-Ribas. 2017. The use of auxin quantification for understanding clonal tree propagation. Forests 8:27. DOI: https:// doi.org/10.3390/f8010027.

Stuepp CA, I Wendling, A Xavier, KC Zuffellato-Ribas. 2018. Vegetative propagation and application of clonal forestry in Brazilian native tree species. Pesquisa Agropecuária Brasileira 53(9):985-1002. DOI: https://doi.org/10.1590/ s0100-204x2018000900002.

Tombesi S, A Palliotti, S Poni, D Farinelli. 2015. Influence of light and shoot development stage on leaf photosynthesis and carbohydrate status during the adventitious root formation in cuttings of Corylus avellana L. Frontiers in plant science 6(973):1-13. DOI: https://doi.org/10.3389/ fpls.2015.00973.

Volis S. 2016. Conservation-oriented restoration-how to make it a success? Israel Journal of Plant Sciences 63(4):276-296. DOI: https://doi.org/10.1080/07929978.2016.1255020.

Wendling I, SJ Trueman, A Xavier. 2014. Maturation and related aspects in clonal forestry-Part I: concepts, regulation and consequences of phase change. New Forests 1:1-23. DOI: https://doi.org/10.1007/s11056-014-9421-0.

Zerche S, U Druege. 2009. Nitrogen content determines adventitious rooting in Euphorbia pulcherrima under adequate light independently of pre-rooting carbohydrate depletion of cuttings. Scientia Horticulturae 121:340-347. DOI: https://doi.org/10.1016/i.scienta.2009.02.012.

Zhao Y. 2018. Essential roles of local auxin biosynthesis in plant development and in adaptation to environmental changes. Annual Review of Plant Biology 69:417-435. DOI: https:// doi.org/10.1146/annurev-arplant-042817-040226. 
